the position occupied by himself in the vivisection controversy. His allusion brings prominently forward (1) That a fact of importance was early ascertained by means of vivisection experiments; (2) that a person of Mr. Tait's acuity, oblivious to experimental results, has quite failed from clinical opportunities to obtain the fact for himself. From Mr. Harrison Cripps' letter I gather there are persons not a few who, having undergone surgical operations involving the peritoneum, can from memory of their own sensations further enlighten Mr. Tait. That the healthy peritoneum is a membrane sentient under mechanical interference is a dictum which Mr. Tait wilh, I imagine, find as difficult to substantiate before the surgeon as before humble followers of Haller's science like myself.

I am, Sirs, yours faithfully,

C. S. Sherrington, M.A., M.D.

The Medical School, St. Thomas's Hospital, Dec. 7th, 1892.

\section{ROE V. NIX AND OTHERS.}

\section{To the Editors of THE LANCET.}

SIRs, - The reports in the daily press of the proceedings in this trial, concluded yesterday, were very short, and a remark which, at the conclusion of my evidence, by permission of the learned judge, I made to the Court was not reported. May I venture to ask you to allow me to reproduce it in THE LANCET? In one of Miss Ellen Roe's letters read in court she said, referring to a visit of mine to her after she had made her will, that $I$ had in joke asked her whether she had remembered Dr. Deas and myself in it. I stated to the Court that I had no recollection of having made this joke, but that if even in joke I had suggested the possibility of any medical superintendent or official visitor being guilty of an act of such grave professional impropriety as to accept a legacy under the will of an insane patient under their control, it was at best but a very poor joke and one which, if made, 1 should desire most emphatically to recall. I felt indebted to Mr. Justice Gorell Barnes for the great courtesy which permitted me to make this public disclaimer.

I am, Sirs, yours truly,

$$
\text { C. LOCKHART ROBERTSON. }
$$

Lord Chancellor's Visitors' Office,

Royal Courts of Justice, Dec. 10th, 1892.

\section{LIGATURE OF THE EXTERNAL ILIAC. \\ To the Editors of THE LANCET.}

SIRS, - In the report of Mr. Makins' case of Ligature of the External Iliac Artery by the transperitoneal method contained in your last issue, reference is made to the fact that I have also operated in the same way. The report goes on to say that "details of the case are wanting." I did tie the external iliac by the transperitoneal method in September last and, so far as the operation went, successfully, but as ten days later gangrene of the leg came on necessitating amputation, I have delayed publication of details until such time as the case is complete. I may perhaps be permitted to add that my reason for adopting the abdominal incision was that the position of the aneurysm rendered the ordinary operation impossible. I am, Sirs, yours faithfully,

Leeds, Dec. 12th, 1892.

W. H. BROWN.

\section{"DEATHS UNDER CHLOROFORM."}

\section{To the Editors of THE LANCET.}

SIRS,-I hope Dr. Van Someren's communication on this subject may meet with the notice which it deserves. It is not flattering to our national vanity that more deaths from chloroform should occur in England than elsewhere. Yet if the matter were fairly investigated perhaps it may be found that the desire to be extra-scientific was the cause of all these misfortunes. What can be more plausible than the supposition that mathematical exactness in the administration of anæsthetics can be attained by the use of specially constructed "inhalers"? These complications are evidently at the root of the evil, and the only point wherein my experience differs from Dr. Van Someren's is as to the absolute safety of a folded towel. I do not doubt for a moment that many have used it, and can use it, without even the shadow of a mischance. But, alas, some are "duffers" and forget the possibility of a fold "going wrong" from the movement of the patient, or even from the manner of folding. As for folded lint, it is simply an abomination. It has not stiffness enough in it to keep its shape, and the result is that in your very last issue a death from this cause at Birmingham has been recorded. By all means let the inhalers be "sent to the lumber room," and let the Italian method (taken from a German source) be adopted-viz., "the mask of Esmarch." This will retain its form in all hands, and can be slightly raised so as to admit more air when required. They have no personal knorvledge of chloroform deaths in most Italian hospitals. I am, Sirs, your obedient servant,

EDWD. HaUghton, M.D.

Spring-grove, Upper Norwood, S.W., Dec. 9th, 1892.

\section{THE RESULT OF THE ROYAL COMMISSION ON VACCINATION.}

To the Editors of THE LANCET.

SIRS, - I have during the last four weeks vaccinated four infants. The vaccination officer of many years' standing has resigned. Would it not be as well to close all vaccination stations and await the result? The Commission would soon have some further demonstration of small-pox $v$ : vaccination, which appears to be necessary. I have applied to my board two or three times to know if they consider it advisable to continue my services.

\section{I am, Sirs, yours faithfully,}

WM. WOODWARD, M.D.

Worcester, Dec. 12th, 1892. Public Vaceinator to the Worcester District.

\section{THE TERCENTENARY CELEBRATION AT PADUA.}

(From our Special CoRrespondent.)

TWENTY-SEVEN foreign and seventy Italian delegates, together with the Senatus Academicus and subordinate teaching staff of the University of Padua, attested the importance attached, not in Italy only but abroad, to the third centenary of Galileo's first lecture on mathematics in that seat of learning. The lateness of the season and its more than usual inclemency explain the non-attendance of many more than the actual representation; but Great Britain is fortunate in having such delegates as Professors Darwin and Norman Lockyer, while America could hardly have had a more accomplished, a more "academically minded" deputy thar Professor William James of Harvard University, where he holds with such acceptance the chair of Psychology. While on this subject I may mention that the letter in which the public orator of Cambridge, Dr. Sandys, conveyed the greeting of his alma mater to the sister University has been greatly admired for its felicitous conception and for its Latin style. Niebuhr remarked that Italian scholars have an almost instinctive sense of Roman genius and Roman form which makes their criticism of modern Latinity peculiarly valuable. If such is the case, then Cambridge may be congratulated on the universal and unqualified eulogy which her public orator's letter has received from the compatriots of Livy.

Earlier in the proceedings than was expected took place in the "ufficio" of the Rector (the Commendatore Ferraris) the presentation of the gonfalone by the ladies of Padua, whose work and gift it was. The fine artistic banner now hangs in the Aula Magna of the University in testimony of the new life to which the womanhood of Italy has at length awakened, a life admirably illustrated on the 5th inst., when in the Scuola Normale Femminile the lady superintendent (the Signora Vittoria Wolf Bassi) gave a masterly lecture on Galileo and his place in the rôle of the sciences before an attentive and highly appreciative audience of her own sex. The lecture may be classed with those already signalised in The Lancer by Professors Mosso and Celli, as indicating the healthy and ennobling influences under which the womanhood of Italy is now growing up.

At midday on the 6th the delegates, Italian and foreign, having been cordially received by the Rector in the Aula Magna, started on a tour of the city, the whole cortège being conveyed in twenty-five carriages. After the public monuments, including Galileo's house, had been duly honoured, an 